\title{
Drama in the Language Lab - Goffman to the Rescue
}

\author{
Isobel Ní Riain
}

\begin{abstract}
In this window-on-practice, I show how I have implemented drama as a means of exploring and practicing the pronunciation of the slender ' $r$ ' $(/ \mathrm{r}$ '/ ) sound in the Irish language and the ' $\operatorname{ch}$ ' $(/ \mathrm{X} /)$ sound. I did this by introducing scenarios where the students invent conversations together around a variety of themes. To this end I established an imaginary 'stáitse' or stage in one corner of the room. Only those students on the stage had permission to speak, the others becoming the audience. In the language lab we created a 'safe space' where students could experiment with language. Goffman's theory helps to interpret what is going on when students speak in this public forum. I found that not only do students not want to appear lacking in linguistic capacity while on stage, they also do not want to appear 'too good' as this could alienate the other students in the group. Language labs have for long relied on technology as a way of teaching and reinforcing good pronunciation of a second language. My students and I also used computer-assisted learning in the lab. However, it soon became clear that the use of drama in the form of scenarios acted on stage provided considerable support for both teaching and learning in the language lab.
\end{abstract}

\section{Introduction}

Between 2011 and summer 2014 I taught Irish in the Modern Irish Department of University College Cork (UCC). I spent one hour a week with each of my two second year groups in the language lab throughout the academic year. Ostensibly, my task was to teach the students to pronounce Irish according to Munster Irish dialects. It was decided to use Relan Teacher software for this purpose. My main objective was to teach traditional Irish pronunciation and thus to struggle against the tide of the overbearing influence of English language pronunciation which is becoming an increasing threat to traditional spoken Irish.

Achieving good pronunciation of Irish language sounds, where there is strong interference from English, is not easy. For many students there is no difference 
between an English / $\mathrm{r}$ / and an Irish $/ \mathrm{r} /$. Irish has a broad and slender $/ \mathrm{r}$ / depending on the nearest vowel. Many students do not even acknowledge that Irish has to be pronounced differently and this is a tendency that seems to be gathering momentum.

The question I asked at the beginning of my research was how could I cultivate a communication context in which students would start to use sounds they had been rehearsing in the language lab. Sounds like 'ch' - /X/ or slender $r-/ r$ '/. I focused on these sounds in particular because they are the most difficult sounds for the students to master. I had noticed that after spending a year practising these and other sounds the majority of students from the previous year had not managed to incorporate these sounds into their speech during the oral exam. I had begun to wonder if work in the language lab was as effective as it might be. It seems that whilst students can imitate the appropriate sounds in class, they do not internalise these sounds by making them part of their normal speech.

After some time it became clear that what was needed in the language lab was the creation of a 'safe space' where students could experiment with sounds and explore different language situations creatively. I realise that my work would benefit greatly from a thorough investigation of social interaction theory and communication theory. I will continue my research this semester and next semester (2014-2015) and I hope to explore these theories in due course. If I combine Gregory Bateson's theory of communication with Erving Goffman's theory of self-representation, I think I may make further progress in understanding what is going on when students engage in role play. It is important to look at role play as a form of 'play' and to take account of the implications this has for communication (Bateson 1985: 178-193). This paper will only give my findings from the work my students and I did in the academic year 2013-2014. Bateson must wait for a future paper.

I was initially motivated to think about my classes in the language lab when I attended a symposium on Performative Teaching and Learning in 2013 in University College Cork. I realised that the work I was doing in the language lab fitted into the approach discussed at that $g$ athering. I decided to pay closer attention to what my students and I were doing and to record my findings in a weekly journal. This paper is based on the notes taken after class each week.

\section{The Language Lab}

The language lab is laid out to facilitate work with computers, each student listening through earphones and working primarily alone using the software package Relan Teacher. The computers dominate the lab. It is even difficult for an average sized teacher to see the students above the tops of the computers. The lab is very unsuited to any kind of conversation. Add to this the fact that we have been hampered by technical problems this year and last year. I decided that a "plan b" was called for.

The innovation I introduced to the lab was to designate one corner which can be seen from everywhere in the room as the 'stáitse' or stage. When a student 
is on the stage $\mathrm{s} /$ he has sole permission to speak. The stage is an imaginary construct but one which has proven very effective. According to Peter Brook:

I can take any empty space and call it a bare stage. A man walks across this empty space whilst someone else is watching him, and this is all that is needed for an act of theatre to be engaged. (Brook 1996: 9)

The purpose of the stage in the language lab is to lend an air of formality to this part of the room. The students have to stand when in this corner. They are visible and exposed. All of this gives the stage and speaking in this public forum a seriousness and a hint of anxiety that forces the students to take seriously what might otherwise descend into farce.

\section{Drawing on Erving Goffman: The Presentation of Self in Everyday Life.}

I have to acknowledge the help of Bärbel Jogschies (Hanover Staatstheater) who advised me to read Erving Goffman when doing this research on the language lab. Goffman is very appropriate for this research as he sees the similarity between what goes on in social relationships, in ordinary conversation for example, and what goes on on the stage. Both of these elements come into play in the language lab.

... almost everyone can quickly learn a script well enough to give a charitable audience some sense of realness in what is being contrived before them. And it seems this is so because ordinary social intercourse is itself put together as a scene is put together, by the exchange of dramatically inflated actions, counteractions, and terminating replies. Scripts even in the hands of unpractised players can come to life because life itself is a dramatically enacted thing. All the world is not, of course, a stage, but the crucial ways in which it isn't are not easy to specify. (Goffman 1972: 78)

In the language lab we work with scripts some of the time and ad lib the rest of the time. According to Goffman people present a version of self when communicating with others socially. This is what he calls a front. Even when the script is being read it is not the same person who is reading it as was speaking with his/her friends before the class. The front a student will show his teacher will not be the same as the front he shows his friends outside the classroom. The student in the language lab is influenced, I believe, by a number of factors regarding the front $\mathrm{s} /$ he shows on the stage, for example.

1. S/he wants to meet the requirements of the lesson and to satisfy the teacher's expectations.

2. S/he wants to have a positive impact on the group by being funny, for example. 
3. S/he does not want to let herself/himself down or feel embarrassed afterwards about her/his performance.

4. S/he does not want to appear better than the others as this might foster resentment towards her/him in the class

The student will put on a front that will try to accomplish each of these priorities. This will not be easy and it may explain why sometimes a student becomes bogged down while on the stage. S/he may not be able to accomplish all of the above at the same time. In this case, s/he will start laughing. Some students will simply go blank in this situation and be unable to say anything at all. Feeling embarrassed is also an important factor here. Goffman writes about saving face. It is important in the language lab that students not be made to feel embarrassed if things go wrong during the role play.

According to Goffman the "performance" is a delicate thing, easily destroyed (ibid.: 63). Sometimes there is a conflict b e tween "h uman s e lves" and "socialized selves", between the different roles that people play (ibid.). People wear masks according to Santayana (ibid.: 65). It may be possible to argue that students speaking Irish may be wearing a different mask to the one they wear when they speak English. And it may also be possible that there is a conflict between these two different personae.

\section{Performative Teaching and Learning}

The approach I take when preparing lessons in the language lab is one of performative teaching and learning. I associate these with active learning. The students have to do things in order to learn something new. They compose conversations, plan scenarios, act out the scenarios, pick up ideas from other students and copy these. This teaching and learning technique can work very well within the classroom as well. It is certainly more effective than expecting students to sit quietly listening to the all-knowing teacher and somehow absorb language from her/him.

Emphasising what the students learn to do is a key part of the education theory known as Constructive Alignment (Biggs and Tang 2009) where TLAs - teaching learning activities - are aligned with learning outcomes which themselves focus on what the student can do at the end of a course of study. Learning outcomes are heavily emphasised by University College Cork.

In their article "Drama in L2 learning: A research synthesis" George Belliveau and Won Kim assert that:

Drama in the language classroom is ultimately indispensable because it offers a lens for learners to use their imagination. It draws upon students' abilities to imitate and express themselves and, if well handled, it should arouse interest and foster personality development. Drama encourages adaptability, fluency and communicative competence. It puts language into context and, by giving learners experience of success in real-life situations, it should arm them with 
the confidence for tackling the world outside the classroom. (Davies 1990: 97 in Belliveau and Kim 2013: 6)

I believe that students can make good progress in language acquisition through drama. Often it is not lack of knowledge that prevents the students from communicating effectively in the language but rather lack of confidence. It is certain that drama contextualises language because the speech involved invokes everyday situations.

Not all teachers are comfortable with using drama in the classroom. Teachers are sometimes afraid that they will lose control of the class if they allow the students to stand up and speak to the group. Teachers need to be trained in facilitating these types of classes.

Some researchers on education who make use of drama in their teaching are Julie Belz (2002), Heather Swenddal (2011), Sirisrimangkorn and Suwanthep (2013). These writers have found that drama works very well as a means of teaching a second language.

I wished to bring a "performative" approach to learning in the language lab. To this end I introduced the following approach in encouraging students to speak and to implement the sounds $(/ \mathrm{X} /$ and $/ \mathrm{r}$ '/) that they had been practising during the first half of the $\mathrm{c} l$ ass. I give the students 'scenarios' to prepare and act out, for example:

Your friend is thinking about quitting university. You give him/her some advice. Make out the conversation orally.

Two students work together on this scenario for about five minutes and then they go onto the stage and act it out.

Student Reaction: The students complain that it is very hard to remember the $/ \mathrm{X} /$ and $/ \mathrm{r}$ '/ sounds while trying to remember the gist of the scenario at the same time. It requires "multi-tasking."

The students in the audience usually find the scenario th ey a r e watching extremely funny. Others amongst them are so preoccupied with their own scenario which is coming up shortly that they are busy rehearsing it in their heads and not taking in what is going on on the stage in front of them. Generally, however, everyone enjoys this part of the class.

My students worked on many scenarios during the academic year; for example, two students acted out a scenario where they were buying a car from a third student and the latter tried to trick them. One student wanted to get married at the age of 19 and four other students acted out the parts of his family and tried to dissuade him from getting married. One scenario involved being at a funeral. The mourners discovered that the dead man has left a lot of money behind. So some of them decided to make sandwiches for the guests whilst the others will went upstairs to search for the money! (Sometimes students get a bit carried away). We acted out many more role plays in addition to these.

The students are actively engaged in their own learning while preparing and acting out the role plays. I see this activity as an example of performative learning. Another activity we practise in the lab is ad-libbing having read a script. Two students read the script they have been working on using Relan 
Teacher on the stage. This script takes the form of a conversation between two young people. I instruct the students to read the script to the end and to then ad-lib the rest of the conversation. The students find ad-libbing quite difficult because they must stay in character. Ad-libbing brings us closer to normal unrehearsed speech.

In order to allow students to talk to each other and to every member of the class, I use some features of the popular dating technique called 'speed dating'. When I ring the bell, borrowed from my mother's mantelpiece, each student has to speak to the person nearest to him/her and continue doing so until I ring the bell again. The student must work his/her way around the class in response to the bells.

\section{Safe Space}

In the language lab I attempt to create a 'safe space' (Gayle, Cortez and Preiss 2013: 1) in which the students can express themselves without shame or embarrassment and without being afraid of being told off. They have to take chances with their performances. This entails "risk-taking" (ibid.). There are at least two risks involved: that they will attempt to make the class laugh and that it won't work and they will be embarrassed or that they will go too far with the humour and the teacher will be annoyed. And of course there is always the risk that the student won't be able to think of anything at all to say and this will result in embarrassment also. As mentioned earlier in this article, Goffman discusses the problem of embarrassment. One problem we faced this year in the language lab was that students wanted to record their classmates performing on the stage and to then put this on Facebook. If this had been permitted, the language lab would no longer have been a safe space and some students might have stopped attending class rather than risk being recorded. I made a strong case against this and the problem was resolved.

\section{The 'Team'}

Goffman writes about the "team" where there is a group working together. There is "intimacy" amongst the members but no "warmth" (Goffman 1972: 88). I would argue that the classroom situation involves a team also and that the team members know each other's strengths and weaknesses. There is a level of intimacy especially in the kind of performative teaching and learning I practice where the students must expose their weaknesses on stage. There can be warmth if the students know each other well and like one another. There could also be hostility if there were jealousy and resentment in the class. Trying to create a 'safe space' in which all the team can function well is primarily the responsibility of the teacher. 


\section{Lessons Learned - Towards an Evaluation}

On a few occasions, I have had to join in the performances on stage because of an odd number of students present in class. I find this experience quite strange as my role as teacher is severely undermined as I become a student and lay myself open for criticism by the audience. I did not feel particularly comfortable in this new role. I also felt under pressure to make the students laugh. This was a heavy burden. In preference to taking part myself, I now ask a student to double up acting in two scenarios. It isn't easy to switch roles mid-class. I have taken the cowardly way out.

I believe drama has a place in many modules of the BA in Irish programme. I taught half a module on storytelling in the Irish tradition this year (2013-2014). I wanted to show the students the difference between a literary story and a folkloric story. To this end I invited a member of the class to retell one of the stories we had read as if he were a storyteller (seanchai). The students then were to note the differences between the two renditions of the story. This student storyteller was also a member of my language lab class and so had had practice of speaking in front of a group, albeit a much smaller group. There are 50 students in the storytelling module. The student told the story without notes in the language lab but the following week resorted to notes when faced with a much larger group in the lecture. I was glad that we had tried this exercise. It did prove, however, that speaking to a large group is a very different experience for the students than speaking to a small group in the language lab. It is much more difficult to create a 'safe space' in a lecture hall containing 50 people.

I have noticed recently that there is a marked improvement in students' ability to integrate pronunciation learned in the lab into role play conversation. They are slowly internalising the $/ \mathrm{X} /$ and $/ \mathrm{r}$ / sounds. Only with constant reminders each week has this now begun to happen and not for all students. A few students persist in the same incorrect pronunciation they displayed at the start of the academic year. For them there is still strong interference from English pronunciation. They persist in pronouncing / $\mathrm{X} /$ as an English $/ \mathrm{k} /$ sound. Thus some of the students say: [ak] instead of [aX]. They continue to pronounce $/ \mathrm{r}^{\prime} /$ as a broad $\mathrm{r}, / \mathrm{r} /$. It is important to note that students vary in the level of seriousness that they attach to the work in the language lab. Some students do not really believe that it matters much whether Irish is pronounced well or badly. Some students feel self-conscious about making a strong / $\mathrm{X} /$ sound. There is sometimes a degree of reluctance involved when students are faced with the possibility of changing their linguistic habits. Be that as it may, some students are intrigued by the distinctive Irish language sounds and embrace the $/ \mathrm{X} /$ and the slender $\mathrm{r} / \mathrm{r}$ '/ sounds wholeheartedly. Internalising the newly learned sounds and making them part of daily use in the Irish language is a difficult process. Students only have access to the language lab in the second year of their Irish language studies. I have noticed that what is learned in second year in the lab can easily be forgotten thereafter.

There is no formal assessment of work in the language lab itself apart from 
comments from the teacher on whether the student is pronouncing the language well or not. The real assessment comes in the form of the oral Irish exam at the end of the academic year. In this exam the quality of students' pronunciation is important.

I believe that there could be a clearer link between the criteria for assessment in the oral exam and the learning outcomes of the work in the language lab. A rubric showing which elements of language competency would be assessed in the oral exam would help students to see the relevance of what was being taught in the language lab. Sadly, students often only appreciate the importance of learning that which will be examined.

\section{Conclusion}

In conclusion, we can say that the introduction of drama and performative teaching and learning generally in the language lab has greatly enhanced the students' learning experience. Their ability to deal with a wide variety of communication situations has increased. They can think on their feet now through the medium of the Irish language. Their pronunciation of Irish is improving slowly. I could see a marked improvement in my students' performance in the oral exam at the end of the academic year. I am convinced that teaching through drama is a very worthwhile and rewarding innovation especially in classes where the emphasis either is or should be on communication. The creation of a 'safe space' is vital to nurturing this experimental communication. The 'safe space' concept is one that could be developed throughout the university not only in language departments but in any department where the voicing of individuals' opinions is valued.

\section{Bibliography}

Bateson, Gregory (1985): Steps to an Ecology of Mind. New York: Ballantine Books

Belliveau, George; Won Kim (2013): Drama in L2 Learning: A research synthesis. In: Scenario VII, 2, 6-26. http://scenario. ucc. ie (Accessed 15 February 2015)

Belz, Julie A. (2002): Second Language Play as a Representation of the Multicompetent Self in Foreign Language Study. In: Journal of Language, Identity, and Education 1, 1, 13-39.

http://dx.doi.org/10.1207/S15327701JLIE0101_3 (Accessed 15 February 2015)

Biggs, John; Catherine Tang (2009): Applying Constructive Alignment to Outcomes-Based Teaching and Learning 1-8. 
Brook, Peter (1996): The Empty Space. New York: Touchstone

Gayle, Barbara Mae Dr; Cortez, Derek; Preiss, Raymond W. (2013): Safe Spaces, Difficult Dialogues, and Critical Thinking. In: International Journal for the Scholarship of Teaching and Learning 7, 2, Article 5, 1-8. http://digitalcommons.georgiasouthern.edu/cgi/viewcontent. cgi? article $=1390 \&$ context $=i j-$ sotl (Accessed 22 February 2015)

Goffman, Erving (1972): The Presentation of Self in Everyday Life. Middlesex: Penguin Books

Sirisrimangkorn, Lawarn; Jitpanat Suwanthep (2013): The Effects of Integrated Drama-Based Role Play and Student Teams Achievement Division (STAD) on Students' Speaking Skills and Affective Involvement. In: Scenario VII, 2, 62-75. http: / / scenario . ucc. ie (Accessed 15 February 2015)

Swenddal, Heather (2011): How drama facilitates language learning: A case for using drama in the second-language classroom.

http://heatherswenddal. myefolio.com/portfolio/papers/ (Accessed 15 February 2015) 